


\title{
ALIMENTAÇÃO E RELIGIOSIDADES NO ROMANCE MENINA QUE VEM DE ITAIARA DE LINDANOR CELINA
}

\author{
Luis Junior Costa Saraiva ${ }^{1}$ \\ Paulo Sergio Oeiras da Silva ${ }^{2}$ \\ Jéssica do Socorro Leite Corrêa ${ }^{3}$
}

\begin{abstract}
RESUMO
O trabalho traz reflexões sobre a relação entre alimentação e saúde no romance Menina que vem de Itaiara de Lindanor Celina. A personagem principal, Irene, descreve parte da sua infância e início de sua adolescência, com um cotidiano bem típico amazônico, entre os saberes culturais presente em toda obra, tendo como cenário a cidade de Itaiara, nome fictício da cidade de Bragança. Destacaremos alguns segmentos da narração que apresentam elementos importantes sobre a relação entre alimentação e religiosidades. A narrativa da obra é em primeira pessoa e a personagem principal descreve momentos de sua memória, momentos em que retrata a cultura patriarcal da época, apresentando valores e costumes religiosos locais. Como resultado da análise, percebe-se que a autora, deixa informações importantes já esquecidas, uma memória literária rica em conhecimento sobre alimentação e religiosidades e os diversos processos de cura.
\end{abstract}

Palavras-Chave: Lindanor Celina. Alimentação. Saúde. Religiosidades.

\section{FOOD AND FAITH IN THE ROMANCE MENINA QUE VEM DE ITAIARA BY LINDANOR CELINA}

\begin{abstract}
The work brings reflections on the relationship between food and health in the romace Menina que vem de Itaiara by Lindanor Celina. The main character, Irene, describes part of her childhood and early adolescence, with a very typical Amazonian life, among the cultural knowledge present in every work, has the city of Itaiara as a scenario, fictitious name of the city of Bragança. We will highlight some segments of the narration that present important elements about the relationship between food and religiosities. The narrative of the work is in first person and the main character describes moments in his memory, moments in which he portrays the patriarchal culture of the time, presenting local religious values and customs. As a result of the analysis, it is clear that the author leaves important information already forgotten, a literary memory rich in knowledge about food and religiosities and the various healing processes.
\end{abstract}

Keywords: Lindanor Celina. Food. Cheers. Religiosities.

Data da submissão 18.11 .2020

Data da aprovação 07.12.2020

\footnotetext{
${ }^{1}$ Graduação em História pela Universidade Federal do Pará UFPA (1999). Mestrado em Antropologia pela Universidade Federal do Pará UFPA (2002). Doutorado em Ciências Sociais na especialidade Antropologia Cultural e Social pelo Instituto de Ciências Sociais da Universidade de Lisboa (ICS) Professor no Campus De Bragança da UFPA, Ligado a Faculdade de Educação e Professor da Pós-Graduação em Linguagens E Saberes Na Amazônia. E-mail: LUISJSARAIVA@GMAIL.COM

${ }^{2}$ Graduado em Letras - Língua Portuguesa pela Faculdade de Letras do Campus Universitário de Bragança da Universidade Federal do Pará (2009-2013). Mestre em Linguagens e Saberes na Amazônia- UFPA. E-mail: oeirasufpa@gmail.com

${ }^{3}$ Graduada em Pedagogia pela Universidade Federal do Pará (2015). Mestra em Linguagens e Saberes na Amazônia- UFPA. E-mail: etieljessica@ gmail.com
} 


\section{INTRODUÇÃO}

A presente análise foi desenvolvida durante a produção acadêmica para a construção da dissertação de mestrado do Programa de Pós-Graduação em Linguagens e Saberes na Amazônia da Universidade Federal do Pará, sob o tema "Reflexões sobre alimentação e saúde no romance Menina que vem de Itaiara de Lindanor Celina". A narrativa da obra é em primeira pessoa e a personagem principal, Irene, descreve momentos de sua memória, na qual retrata a cultura patriarcal da época. Nesta obra, Irene descreve parte da sua infância e início de sua adolescência, cotidiano, inquietações e traquinagens, que tem como pano de fundo a cidade de Itaiara, nome fictício da cidade de Bragança, local no qual é ambientado o romance.

A cidade de Bragança-PA, fica localizada a aproximadamente $210 \mathrm{~km}$ da capital do estado, muito conhecida pela produção de farinha d'água, além de destaque na atividade pesqueira e nas manifestações culturais. Muitas características da cidade são apresentadas no romance, as manifestações culturais, características sociais e estruturais da cidade, e muitos elementos de caráter alimentar. No presente artigo, destacaremos algumas narrativas que apresentam as variadas propriedades da cultura alimentar, saúde e religiosidade, e suas diferentes significações.

A cozinha sempre se configurou como um amplo espaço de análise sociocultural, um conjunto de elementos que perpassam pelas significações dos produtos utilizados, seu modo de preparado e o ritual de produção e consumo. Na obra Menina que vem de Itaiara, Irene narra diversas situações vivenciadas por ela e nos apresenta alguns desses elementos característicos do contexto amazônico, na qual percebemos bem forte a presença da tradição alimentar, principalmente por conta da época em que o romance foi escrito, período de pouca tecnologia, baixa influência da mídia televisiva com suas propagandas alimentares bem atrativas, seduzindo para as refeições rápidas, porém de baixo poder nutricional e alimentar, e consequentes prejuízos à saúde e ao bem estar. Assim, os hábitos alimentares tradicionais do romance não possuíam a concorrência que facilmente visualizamos nos dias atuais, proporcionando uma alimentação bem mais saudável, os alimentos usados, em sua maioria, eram oriundos de recursos naturais, por vezes, colhidos no pomar do quintal da casa de Irene.

Os recursos naturais não apresentavam substâncias que hoje causam mal à saúde, como agrotóxicos, produtos utilizados na agricultura para controlar insetos, doenças, ou plantas daninhas que causam danos às plantações. Era bem mais fácil encontrar casas com suas próprias criações, tais como criações de galinhas, de patos, de perus, de porcos etc. Em todo romance, isso é algo bem presente, principalmente quando se reuniam para certas ocasiões em que eram servidos pratos típicos da Amazônia. Esta é a diferença atual para o que era frequente durante a construção do romance, os elementos que foram inseridos, algo daquele momento vivido, os tipos de alimentos, as configurações das casas, com espaços maiores em que se podia plantar, o espaço envolvido, pois de lá saía o leite, a carne, os grãos, as frutas e as verduras e, ocasionalmente, funcionavam as trocas. Se alguém matava um porco, era repartido com os outros vizinhos. Trata-se de um costume que muitos conheceram em alguns interiores e, ainda, em ocasiões a prática continua em datas específicas.

Os elementos culturais na culinária herdada dos nossos antepassados estão presentes também nas manifestações religiosas. Esta situação, de alguma forma, propicia uma sintonia com o ser divino e deixa claro que a religião é um dos sustentáculos de uma cultura. As manifestações religiosas demonstram a necessidade do homem para se comunicar com o sobrenatural, para auxiliá-los em suas necessidades. Atualmente, algumas características permanecem. Portanto, fatores religiosos influenciaram profundamente em certos hábitos alimentares.

Trocas sobre experiências alimentares ocorrem quando diversas culturas se encontram no mesmo espaço, quando relacionadas a diversidade entre natureza e sociedade, resultando 
em combinações que reproduzem emoções nas degustações, nas diferentes formas de práticas alimentares. Alimentos que possuem, para determinado grupo social, propriedades curativas e míticas.

A alimentação é um tema presente em livros religiosos sagrados, como na Bíblia, os quais destacam os elementos alimentares ou ainda as proibições alimentares, como no Livro de Gênesis.

E disse Deus: Produza a terra erva verde, erva que dê semente, árvore frutífera que dê fruto segundo a sua espécie, cuja semente esteja nela sobre a terra. E assim foi. E a terra produziu erva, erva dando semente, conforme a sua espécie, árvore frutífera, cuja semente está nela conforme a sua espécie. E viu Deus que era bom. (GÊNESIS, 1,11-12).

Ainda em um outro livro sagrado da Bíblia, temos a seguinte passagem, "E seu fruto servirá de alimento e a sua folha de remédio" (EZEQUIEL, 47, 12). Segundo Balbach (1968), essa ciência terapêutica vem desde a Antiguidade. Claro que no início não existiam tantas enfermidades, mas, com o decorrer do tempo, a força física do homem foi diminuindo, em virtude das consequências das leis da natureza que foram sofrendo mudanças causadas pelas mãos do homem. Assim, os homens foram tratando das enfermidades como melhor podiam, e nada melhor para isso do que recorrer à natureza, que foi o primeiro médico e remédio da humanidade.

Em Menina que vem de Itaiara, Lindanor Celina retrata a infância da personagem numa cidade interiorana, que ainda tem nos saberes tradicionais a solução para diversas situações relacionadas à saúde, típicas de comunidades tradicionais, que buscam em ervas e chás a cura para diversos males, dos mais leves aos mais complexos. Esse conjunto de saberes está muito presente na experiência dos personagens criados por Lindanor ao longo da obra, como, por exemplo, no Marreca, rezador de garganta, ou na Vijoca, experiente em remédios naturais, e outros que serão tratados ao longo do presente trabalho.

Sobre o saber tradicional de comunidades amazônicas Lima (2009) diz que

são características de componentes de populações tradicionais, a percepção dos sons da mata, sejam diurnos, noturnos, rastros, odores, conhecimento das espécies da fauna e flora e o uso adequado que se faz dessas espécies" e ainda "muitas habilidades presentes nas populações tradicionais, como o conhecimento das funcionalidades de ervas e sua manipulação para confecção de ungüentos, xaropes" (LIMA, p. 4).

Analisando a relação entre alimentação e saúde na obra, percebemos que Lindanor Celina concilia essa variedade de alimentos regionais com hábitos, costumes e culturas, pois está interiorizada em seu trabalho. Hábitos adquiridos por crenças, valores e agentes sociais, que praticam uma vivência de tradições, uma ciência tradicional que está inserida nas personagens, transmitindo a importância dos saberes históricos culturais. Apresenta também soluções por meio de elementos religiosos acompanhados de alimentos, ervas e outras práticas.

Assim, os hábitos e práticas alimentares produzidos historicamente se transformam em hábitos culturais que integram o modo de viver deste grupo social ou povo. Considera-se também que numa sociedade capitalista não existem hábitos e práticas alimentares homogêneas, pois existem hábitos que, mesmo desejados por todos, não podem ser transformados em práticas por grande parte da população. (PACHECO, 2008, p. 222). 
O conceito de cultura apresenta, de alguma forma, um padrão que deve ser respeitado, pois está representando significados que dominam certos grupos de pessoas, símbolos que historicamente se perpetuaram, mas que nem sempre são bem vistos por todas as pessoas. $\mathrm{E}$ essa cultura vem junto com a religiosidade de cada um. Existe uma religião dominante, o Cristianismo, que, talvez por isso, nem sempre são aceitos outros tipos de crenças, ou seja, mais difíceis de segui-las, porém, há um sincretismo de costumes, que vêm sendo repassados em cada cultura.

\begin{abstract}
$\mathrm{Na}$ crença e na prática religiosa, o ethos de um grupo torna-se intelectualmente razoável porque demonstra representar um tipo de vida idealmente adaptado ao estado de coisas atual que a visão de mundo descreve, enquanto essa visão de mundo torna-se emocionalmente convincente por ser apresentada como uma imagem de um estado de coisas verdadeiro, especialmente bem arrumado para acomodar tal tipo de vida. (GEERTZ, 2012, p. 67).
\end{abstract}

O que seria essa visão de mundo para este autor? Como são vistas as práticas religiosas nas culturas? Veremos, a seguir, um pouco desta prática religiosa relacionada a elementos alimentares tratados pela autora no romance, que destaca informações importantes da visão de mundo do povo amazônico, e como cada atitude, cada alimento, se torna tão aceitável pelas pessoas. Se percebe como a religião toma forma nas ações humanas, permitindo mudanças em determinados padrões de vida.

\title{
1 PRÁTICAS ALIMENTARES E CURATIVAS NO HIBRIDISMO RELIGIOSO
}

A narrativa na obra Menina que vem de Itaiara organiza um conhecimento social daquele determinado momento, que explica um pensamento comum do período. No romance, encontramos características marcantes da religião africana, que poderia ser candomblé ou umbanda. É o caso da palavra mandinga ${ }^{4}$, que é uma forma de exercer uma medicina mágica e simpatias, crenças herdadas de homens escravizados, oriundos da África. Encontramos também elementos da religião católica em sincronismo com outras religiões, ou ainda da forte presença do espiritismo. A obra termina por trazer ao longo das páginas a presença do sincretismo religioso tão presente em nosso país.

Com a presença dos africanos no Brasil Colônia, as diferentes religiões e/ou os cultos tradicionais dos diversos grupos étnicos foram-se assimilando, para, num primeiro passo, paulatinamente constituírem o que se costuma chamar de candomblé e, num segundo instante, estabelecerem um diálogo também com a religião católica e os cultos indígenas, adotando elementos destes. (ROMÃO, 2018, p. 362).

Como a Religião Católica era a dominante, imposta durante a "catequização" feita pelos primeiros colonizadores, após o comércio de pessoas escravizadas trazidas para o Brasil do continente africano, estes criaram estratégias para a sobrevivência de suas religiões maternas.

\footnotetext{
O sincretismo religioso afro-brasileiro como aspecto cultural foi - e continua a ser uma estratégia de sobrevivência transnacional, pois teve sua origem exatamente no desarraigamento de milhões de africanos pela via da chamada passagem do meio. Também o entendemos como transnacional, porque sua complexidade temática se estendia - e ainda se estende - às mais diversas áreas da convivência e das vivências humanas: rituais religiosos, conteúdos históricos, práticas sociais, lendas e mitos como substratos culturais, e toda uma gama de outros fatores (ROMÃO, 2018, p. 368).
}

${ }^{4}$ MANDINGA - termo de origem africana para feitiço. 
Esses grupos de pessoas não tinham a liberdade para cultuarem suas divindades e, para enganar seus senhores, criaram as próprias estratégias para persuadi-los. Começaram, então, a usar as imagens de santos católicos, como táticas de sobrevivência, para encobrir seus orixás, caso não procedessem assim seriam pegos e advertidos, até por causa de elementos como a Inquisição ${ }^{5}$ que no Brasil teve início no período colonial, pois a Igreja jamais aceitaria e nunca aceitou tal ato. Então, surgiram santos que transitaram, e até hoje transitam, pelas religiões africanas e católica, o São Sebastião, São Benedito, São Cosme e Damião, santos de origem católicas, mas que também são cultuados nas religiões de origem africana.

Com certa facilidade encontramos pessoas em eventos católicos, por exemplo, na festividade de São Benedito em Bragança, promesseiros, marujos, que vêm pagar suas promessas no período da festa, mas que raramente puseram seus pés em outros momentos na igreja católica, exceto neste período. Justamente porque tais promessas foram feitas em terreiros, durante rituais de candomblé ou de umbanda etc. Pois tais imagens de santos estão presentes nas outras religiões.

Há um filme nacional chamado O Santo Milagroso, de 1967. É um filme de humor, no qual dois personagens retratam a fé em diferentes situações, um padre e um pastor que disputam seus fiéis, e um coroinha que se apaixona pela irmã do pastor. No decorrer do filme o coroinha é proibido de se encontrar com a mocinha da história, mas acaba fazendo uma promessa em um terreiro de umbanda, no intuito de conseguir a jovem, porém o padre e o pastor se envolvem num conflito que finda fazendo uma imagem do Santo Antônio "falar". No final da trama, os jovens ficaram juntos e o milagre foi atribuído ao santo. O filme retrata essa realidade de mistura, esse sincretismo entre religiões, adquirindo costumes, mas que não fazem parte de certas doutrinas religiosas, são aspectos adquiridos pelo próprio indivíduo.

É importante lembrar que no Brasil raramente se encontrará um panteão de origem
africana totalmente baseado apenas em uma etnia. Costuma-se encontrar em um
mesmo candomblé uma divindade de origem ioruba, p. ex. Oiá, também conhecida
como Iansã, ao lado de outras divindades assimiladas, à guisa de exemplo, das
práticas religiosas da omeanas, como Oxumarê, Omulu e Nanã Buruku. Com o
tempo, o sincretismo originou uma religião tipicamente brasileira, mesclando
diversos elementos de outras religiões e crenças, mas com base primordialmente nos
cultos africanos, nos rituais indígenas e no catolicismo: a umbanda. (ROMÃO,
2018, p. 368).

Em se tratando de religiosidade, não há prática totalmente pura, mas um hibridismo religioso, que é muito presente no contexto brasileiro de um modo geral e algo muito presente na obra de Lindanor.

Vamos explorar um pouco mais a medicina rústica (práticas médicas populares), como resultado de uma série de aculturações da medicina popular da cultura portuguesa, indígena e africana. Para tanto, é necessário o conhecimento das influências que ela sofreu dos antecedentes pré-ibéricos, lusos, ameríndios e africanos. Não devemos olvidar os antecedentes que a medicina popular negra recebeu, quando estiveram em contato com a África branca - os mouros. Todavia, o novo ambiente e novos contatos proporcionaram, para ambas as partes, novas experiências como os elementos que o ameríndio, e o novo habitat, lhes ofereceram. (ARAÚJO, 1959, p. 43).

Araújo diz que "o pajé ameríndio, o feiticeiro negro, o bruxo europeu, certamente tiveram suas técnicas de lidar com o sobrenatural, num dado momento em contato" (1959, p. 44). Ainda, segundo o mesmo autor, ele faz uma classificação para o estudo da medicina

${ }^{5}$ Tribunal de Santo Ofício, foi um movimento da Igreja Católica Romana, criado para combater a heresia, em que os supostos hereges eram julgados, torturados e até a morte na fogueira. 
rústica em medicina mágica, medicina religiosa e a medicina empírica, pois para cada tipo de doença há um determinado remédio, enfim, a causa do mal está sempre no sobrenatural, daí haver uma certa unidade entre essa classificação.

Em Menina que vem de Itaiara, temos, então, o personagem Marreca, exímio rezador de garganta e alguém que representa bem essa junção entre religiosidade, medicina e poderes de cura no sobrenatural. Abaixo temos a descrição do trabalho do benzedor, o qual percebemos que nesse tipo de ofício não tem hora para ser chamado, todo momento torna-se oportuno, precisou logo era chamado, à semelhança dos profissionais da saúde pública, a necessidade de socorrer fazia parte dos padrões de cultura, e a fé depositada no benzedor ia além de um simples conhecimento, a crença regia toda a comunidade. Tudo estava voltado para o sobrenatural. A mistura das religiões era bastante comum. Não se percebia as diferenças, preconceitos ou algo similar, e sim algo corriqueiro, faziam parte das narrativas populares. Era comum esse tipo de prática. As doutrinas religiosas não eram de conhecimento do povo. Tudo era mais simples, e se algo era proibido, por exemplo, pela Igreja Católica, certos rituais, não eram de conhecimento ou não se aplicava tanta importância. Fazia parte dos costumes do povo. Em toda região sempre havia mais de um benzedor, alguém que portava tais poderes. Era muito importante a presença de uma pessoa que pudesse aliviar o sofrimento alheio. Sempre era bem-vindo um benzedor. Ele gozava de um respeito, assim como também podia ser temido, uma vez que algumas pessoas confundiam suas práticas como o mundo obscuro do sobrenatural.

Uma vez, no jantar, engoli uma espinha de peixe. De tainha. Era de noite, grande foi a agonia. Debalde me fizeram cuspir no prato que rodaram três vezes, à toa ingeri punhados e punhados de farinha enxuta, da bem brolô, pirão, banana. Em vão mamãe bradou: "São Brás, valei-me" não sei quantas vezes. São Brás, nem, nem. Certamente operava gargantas noutro canto do mundo, distante demais da rua do Capim. Pois dois dias passei naquela situação. Dormia uns pedaços, quando o sono podia mais que o incômodo, a dor, isso mesmo de boca aberta sobre um travesseiro, babando sem destino. Os vizinhos acudiram, era mais quem ensinava mezinhas, simpatias. Mas a espinha saiu quando bem quis, aliás, quando o Marreca chegou ..." (CELINA, 1997, p. 115).

Fui-me deixando operar. Ergui o queixo, conseguinte ele mandou, e Marreca começou a encostar a lâmina em minha garganta, calcando-a de leve, não pelo fio, mas pelo lado, enquanto pronunciava sua reza, baixinho, aos cochichos. Debalde busquei entender palavra que fosse da benzedura, ele falava mais para dentro, muito balbuciado. Só conto de certo isto: no medo, depois atenção em que fiquei, esqueci a espinha, o mal-estar, a dor na garganta. Quando dei por mim, cadê espinha? Fora-se, descera evidentemente, eu nem sentira. Eu que há quarenta e oito horas só falava por mímica e boca não tinha senão para babar. Engoli em seco repetidas vezes, experimentando, e falei alto: "Mamãe, a espinha passou". "Desceu mesmo, minha filha, verdade? Deus seja louvado!" (Idem, p. 117).

Nos trechos acima, alguns elementos merecem análise. Um deles, refere-se ao consumo alimentar de peixes, um dos peixes que ainda hoje é bastante consumido em Bragança é a tainha, e é exatamente uma espinha desse peixe que engata na garganta de Irene. Toda alimentação deve ser bem mastigada, para não correr o risco de se ingerir uma espinha inteira. O peixe é um dos alimentos que requer um cuidado maior ao ingerir. Qualquer descuido pode resultar no perigo da espinha ingerida ficar presa na garganta, causando grande desconforto e consequente dor naquela região. A espinha pode ficar presa na garganta por dias. Daí a importância ou necessidade de alguém com habilidades para retirá-la. O peixe é um dos alimentos preferidos das comunidades da região bragantina, por ser esta uma região costeira, tão próxima da costa oceânica. Cabe notar que a personagem não é de imediato levada ao hospital, para que seja submetida a algum tratamento médico, e sim submetida aos 
cuidados do Marreca, um benzedor conhecido pelos personagens do romance por suas habilidades de benzimento, reza e cura; Um pouco antes, a mãe de Irene, clama por São Braz,

\begin{abstract}
São Brás nasceu na cidade de Sebaste, Armênia perto do ano 300. Num certo tempo, começou a questionar sobre sua profissão de médico, pois queria servir a Deus, mas não sabia como. Resolveu, então, tornar-se um eremita e ficar em constante oração. Assim, viveu numa gruta por muitos anos.

Um dia, uma mãe desesperada o procurou porque seu filho estava quase morrendo com um espinho encravado na garganta. São Brás olhou para o céu, rezou e, em seguida, fez o sinal da cruz na garganta do menino. No mesmo instante, ele ficou milagrosamente curado. Por esse milagre, até os dias de hoje São Brás é invocado para curar os males da garganta.

Em todos os lugares do mundo, quando uma criança ou qualquer pessoa se engasga, a invocação direta ao Santo logo é rezada: "São Brás te proteja." Ou simplesmente: "São Brás."6
\end{abstract}

São Braz era um santo conhecido por curar gargantas, conforme comprova o relato acima citado. A mãe de Irene ao vê-la em sofrimento com a espinha na garganta, clama ao Santo (São Braz), na busca de um repentino milagre, porém o socorro por parte do santo não vem, embora a mãe clame inúmeras vezes. Só que logo que chegou o Marreca, o responsável de fazer a espinha sumir da garganta, utilizando uma faca e uma reza, que o texto não deixa claro se essa reza foi a São Braz ou direcionada a outro santo, mas a cura da garganta é atribuída ao benzedor. A espinha sumiu durante a reza que Marreco fez no momento em que "passava a faca" na garganta de Irene e balbuciava orações, que a personagem não conseguia compreender o que ele pronunciava, embora se esforçasse para isso.

Cada pessoa tem dentro de si um conceito de religião e crendices. Por isso, alguns são capazes de conhecer e colocar em prática maneiras particulares de resolverem problemas de imediato. Percebemos que no romance é muito forte essa presença mítica. A fé depositada em certas simpatias, alimentos, frutas e ervas, se fazem muito presentes no momento tratado na obra. Sempre era mais comum primeiro recorrer a pessoas como o Marreca, com costumes e culturas herdadas pelas raízes étnicas, do que recorrer a um médico, visto que, nesse momento, era mais difícil o acesso à medicina canônica. Os meios naturais eram os mais acessíveis e utilizados.

As doenças e suas causas nos induzem a saber melhor qual tipo de medicina onde as classificamos. Assim a cura de uma doença provocada pela quebra de um tabu (medicina religiosa) terá que se processar através de um ritual. Não importa que entre nesse ritual, por exemplo, o uso de um vomitório ou chazinho (Medicina empírica). (ARAÚJO, 1959, p. 45).

O personagem Marreca era um "rezador contra espinhas de peixe, maus-olhados, quebrantos, esipras" (CELINA, 1997, p. 116). Mas, conforme está no romance, não é um simples rezador, devido as suas atividades, mas alguém respeitado por seus poderes de cura. Antigamente, encontravam-se muitas pessoas com essa denominação. Eram apenas rezadores ou benzedores. Hoje, a maioria são idosos, muitos já morreram, alguns chegaram até passar esses ensinamentos e práticas para os seus filhos ou netos, mas estes, na maioria das vezes, rejeitaram dar continuidade.

"No candomblé a medicina é mística, é sacerdotal, sua terapêutica não é mágica e sim religiosa" (ARAÚJO, 1959, p. 46). Vamos entender um pouco mais sobre essa medicina mágica, uma vez que, segundo Araújo (1959), há uma diferença entre benzedura e simpatia, embora ambas sejam do ritual protetivo, ambas também apresentam um conjunto de gestos,

${ }^{6}$ Informações disponíveis no site: https://cruzterrasanta.com.br/historia-de-sao-bras/132/102/. 
rezas e palavras com as quais as pessoas procuram alcançar a cura, proteção da saúde ou prevenção dos males.

Fica entendido que a benzedura só é feita por oficiais especializados. Desta forma, teremos o curador de cobras (especialista), o curador e o benzedor (clínica geral). Já a simpatia é uma forma de secularização da benzedura. A sua execução não depende de um oficial especializado, qualquer pessoa que queira se disponibilizar poderá executá-la. Por isso, a simpatia passa a sensação de cura, proteção e prevenção. A simpatia não precisa ser executada como a benzedura, qualquer pessoa leiga pode fazê-la. Já a benzedura não pode ser feita por qualquer pessoa. O benzedor não ensina sua prática, a não ser em dias especiais, para alguém que esteja iniciando, se o benzedor pressentir sua morte na sexta-feira Santa, dia 25 de março, dia dos mortos ou dia de Natal. A importância desses dias é que, fora dessas datas, perderá a força para realizá-las, ficará 'quebrado'. Ao passo que as simpatias podem ser ensinadas a qualquer momento, e não implicam a perda de forças. Por isso, a benzedura e as simpatias são empregadas por meio das rezas e as características dessas ações são os gestos, as palavras, que fazem desaparecer o motivo ou a própria doença. " $\mathrm{O}$ curador, rezador, ou "benzinheira" tem o poder de fazer passar de um ser humano para animal ou daquele para uma cousa, é a transferência, técnica muito usada" (ARAÚJO, 1959, p. 49).

$\mathrm{Na}$ região bragantina os mais velhos costumavam chamar para essas pessoas de benzedeiras, muitas já falecidas, geralmente usavam para as suas rezas um tipo de mato chamado "vassourinha", outras vezes pião roxo e, na ausência dessas plantas, usavam o alho. Os gestos eram em cruzes ou o sinal da cruz (símbolo do cristianismo). Geralmente durante essas benzeções tais plantas murchavam, era o sinal que o quebranto saiu e aquelas folhas teriam absorvido todo o mal do corpo. Pois, como bem afirma Araújo sobre a magia

a sua razão de ser repousada na lei da magia da transferência. Outras vezes é a 'benzinheira' a pessoa que tem a força para mandar o quebranto para as areias gordas do mar sagrado. (ARAÚJO, 1959, p. 49).

As personagens presentes na obra ainda hoje se configuram no cotidiano de cidades como Bragança. Em Aráujo, a oração se escutava um pouco o que rezava, mas as da região bragantina, não se escutava nada, apenas usavam gestos com as mãos fazendo cruzes na testa, na costa, nas mãos, e elas bocejavam bastantes dizendo que a criança estava com muito mal olhado, lacrimejavam bastante. Quando isso acontecia, geralmente, as pessoas iam em busca das benzedeiras, que passavam mais credibilidade durante as sessões de benzimento.

Sobre a cabeça da criança com um raminho verde (o que vimos casualmente era jumeira, poderia ser de arruda, guiné, etc.), enquanto fazia cruzes, rezava. $\mathrm{O}$ benzimento para surtir efeito deve ser executado durante três dias seguidos de manhã com a criança ainda em jejum. No primeiro dia, com uma folha, no segundo com duas, no terceiro com três. Quando é arruda ou guiné pó benzimento é feito com um pequeno galho. Deve-se ter cuidado de lança-lo na água corrente, atirando com as costas voltadas para o rio, sem olhar para traz, mandando que em nome de Deus, dos santos e da Virgem Maria que o mal siga para as águas do mar sagrado, deixando a vitima da moléstia sã e sossegada. (ARAÚJO, 1959, p. 52).

Naquela época se a criança estivesse com a cabeça quente, o benzedor tirava o sol da cabeça, com uma fralda enxuta, ou guardanapo, na cabeça e um copo cheio de água. Colocava os dois juntos na cabeça. Enquanto não parasse de borbulhar, ela rezava. Segundo Araújo (1959, p. 50) "coloca na cabeça do doente um pano branco e uma garrafa branca cheia de água até o gargalo; vai rezando; benzendo, quando a doença começa a sair a água ferve". Também tirava o ventre caído, quando as crianças apresentavam diarreia e febre repentina, após alguém ter levantado a criança acima da cabeça. Para o que conhecemos atualmente, 
qualquer doença, diarreia ou vômito em uma criança jamais vai se dizer que foi algo provocado por certos comportamentos humanos, o que se vai dizer é que pode ter adquirido alguma bactéria, e a criança é levada imediatamente para o hospital, jamais vai se dizer que uma dor de cabeça foi causada pelo sol, a não ser uma insolação que é visível. A questão aqui de todo esse conhecimento e sabedoria, os mais antigos dirão que foi por "mau olhado", ventre caído ou outras doenças que somente uma benzedeira pode tirar, caso contrário, vão levar para um médico, não vai ficar curada, pois não é doença causada por bactérias, e não acreditavam em superstições.

$\mathrm{Na}$ citação a seguir, temos no exemplo da curandeira, mais uma personagem do romance que utiliza seus saberes sobre plantas e alimentos que curam.

Pelo décimo segundo dia da doença, apareceu em casa a Vijoca. Vijoca, tempos em tempos vinha à cidade, ali se demorava mais ou menos um mês, receitando, pondo emplastros, benzendo e fomentando, dando passes, com suas artes de curar. Era aqui e acolá, dum lado e doutro, Itaiara, Bragança, Carutapera, Viseu, não parava, sempre chamada para ver doente. Não chegava para as encomendas. Mamãe, que padecia de umas dores de madre, há dias mandara chama-la. Procurada como era, a Vijoca demorou-se. Quando veio para ver mamãe, achou foi o povo todo fazendo quarto à minha irmã desenganada.

- Ai, dona Vijoca, lhe chamei para mim, mas quem está mal é minha filha!

Bem calma, a fala tranquila, a Vijoca olhou longo e atentamente a menina, e pediu um dente de alho. Com o dente de alho benzeu Stela, acabou, parou, assim uns instantes, como quem escuta. Falou, sempre o mesmo descanso na voz: "Eles estão dizendo que foi vento na nuca que ela pegou".

A Vijoca, sem dizer palavra, atenta, como se escutasse ainda as suas vozes: "Eles estão dizendo que se fizerem o remédio direito, como eu vou ensinar, ela fica boa, e fica perfeita". Houve um silêncio. E pela primeira vez mamãe sorriu.

A curandeira pediu papel e lápis. Sentou-se, muito lenta, junto à mesa da sala de jantar, apanhou a xícara de café quentinho que a Rita lhe trouxera, pediu a papai que escrevesse (era analfabeta) e foi ditando:

"Urina de três meninos

hortelã de três qualidades: de panela, hortelã-pimenta ${ }^{7}$

e verga-mota (erva morta)

tabaco torrado

sal na mãozinha..."

- Sal na mãozinha? - interrompeu mamãe. "Sim. Senhora pega um pouco de sal que dê para encher a cova da mão da criança, sal esse que se torra e se mistura à hortelã para ser socado". Prosseguia:

"Álcool canforado

gergelim

mamona

azeite doce

óleo de amêndoas também doces.

Soque tudo, ponha numa cuia de coco, junte a urina dos três meninos, e leve ao fogo para esquentar. Com a mistura, bem aquecida, faça três fricções, uma por noite, três noites seguidas. Depois nove pílulas contra estupor, uma banda por noite, são dezoito noites. Dê as pílulas desmanchadas no leite de mulher que estiver criando um menino. Ao fim dos dezoito dias, fazer, três dias seguidos, três chás de palha de

${ }^{7}$ HORTELÃ - Mentha piperita - Família: Labiadas. Outros nomes: Hortelã- pimenta, menta. Descrição: Planta de 30 a $60 \mathrm{~cm}$, ligeiramente aveludada. USO MEDICINAL: Na hortelã estão reunidas, em elevado grau, as propriedades antiespasmódicas, carminativas, estomáquicas, estimulantes, tônicas, etc. Prescreve-se a hortelã como remédio na atonia das vias digestivas, flatulências, timpanite (especialmente a de causa nervosa), cáuculos biliares, icterícia, palpitações, tremedeiras, vômitos (por nervosidade), cólicas uterinas, dismenorréia. É um medicamento eficaz contra os catarros das mucosas, já porque favorece a expectoração, já porque combate a formação de novas matérias a expulsar. Aplica-se o sumo embebido em algodão para acalmar as dores de dente. (BALBACH, 1968, p. 252). 
alho, bem fortes. Que é para cortar o mal pela raiz, eles estão dizendo (CELINA, 1997, p. 104-105).

No romance Vijoca representa uma figura popular. As pessoas depositavam uma confiança em função dos favores e conhecimentos curativos, suas ações de curandeira, esse mistério envolvendo o espiritual e as crendices mais conhecidas. Pois as pessoas presentes na história, no caso a família que aceita essa ajuda, essa oração, ou remédios, como emplastos, banhos receitados por curandeiros, representam pessoas reais que, pela religiosidade, são mais fáceis de aceitar ou de serem manipuladas. Aqui, no entanto, não se trata de manipulação, mas de fé. Algumas pessoas que se dedicam a esses trabalhos não cobram qualquer valor em dinheiro, mas podem receber ajudas ou troca de favores, até porque diziam que era um dom recebido de Deus. Atualmente, os curandeiros são conhecidos por praticarem medicina tradicional. Segundo Araújo (1959), o curandeiro não ensina suas rezas, geralmente seguem o calendário religioso. Em determinadas épocas recorrem à religião para adquirir mais forças pela confissão.

Jajaba, pai-de-terreiro do candomblé, no dia 15 de agosto confessou.
"Pernambucano, assim era chamado Artur Francisco da Cruz, o presidente do tore
que funciona à Rua Socorro, também confessou nesse dia. Entrevistados, ambos
disseram o que resumimos: quando a gente tem um trabalho grande e precisa de
mais forças é bom confessar e comungar". Santos e divindades seriam então os
oficiais da medicina mágica. E muitos padres, sem o saber, se tornam os
ministradores das "forças" e "virtudes" a muitos dirigentes de tore, candomblé ou
curadores que na igreja aparecem em determinados dias com fito exclusivos de
recebê-las (ARAÚJO, 1959, p. 74).

O benzedor ou curandeiro tem seus segredos e seguem rituais religiosos próprios, e buscam reforços no Catolicismo no intuito de intervenções nas coisas sagradas, e de certa forma proibidas pela Igreja, quando usadas indevidamente. Dentro dessa perspectiva, os trabalhos, as benzeções têm resultados imediatos pelo sobrenatural com auxílio de elementos da natureza, como ervas e outros tipos de alimentos, pois junto com tais elementos, recebem em oração como um encantamento, como uma fórmula mágica, uma espécie de energia benéfica no que será ingerido ou utilizado para expulsão da doença ou outros males no corpo.

\section{ALIMENTOS QUE CURAM}

As ervas medicinais presentes na obra em questão são bem frequentes e corriqueiras na vida dos bragantinos. Na época retratada pelo romance, nas zonas rurais era muito comum as casas terem em seus quintais ou terrenos plantações ou hortas medicinais, com um variado tipo de ervas de poder curativo, que serviam para diversos tipos de doenças, tais como: gripes, resfriados, dor de cabeça, cólicas etc., conforme afirma Balbach "Assim, as plantas têm esta tríplice tarefa: Alimentam e curam o homem e purificam o ar" (BALBACH, 1968, p. 52).

Vejamos o exemplo da personagem Rita que, com os efeitos do período menstrual, recorria-se ao uso de chá de ervas para amenizar o incômodo destes dias.

A Rita todo santo mês, ô martírio! Três dias malacafenta, o primeiro então, certo passá-lo inteirinho deitada, gemendo, na rede, no quartinho aos fundos do alpendre, uma garrafa de água quente na barriga. E suava, ensopava camisões, se torcia de dores. Mamãe fazia chá de sene e lhe levava, quente, ralhando: - "Tá pensando que é canja, dona moça? Vá, vá andar na terra escaldando, vá dançar no morro até essas tantas, vá! Pensa que é brincadeira de menina fêmea? Mulher é bicho fino, qualquer coisinha se arrebenta. 
A coitada engolia o chá pelando, mais as descomposturas, calada, fungando o choro, bufando de dor.” (CELINA, 1997, p. 195).

Neste trecho, enfatizamos a natureza feminina, contada de uma forma mais popular e a solução caseira para o desconforto causado neste período eram os chás, que segundo a narrativa, eram tomados sem muitas regalias. A forma de tratamento apresentada no discurso retrata algo típico das mulheres interioranas, alguns cuidados nesta fase eram recomendados, e deveriam ser cumpridos rigorosamente.

Os tabus estão presentes nas mais diferentes fases da vida e são significativos para o bem-estar do corpo e a preservação da saúde. Por exemplo: mulheres durante a menstruação devem evitar o consumo de abacaxi, melancia e jaca dura para não inflamar o útero; outra regra geral é a proibição de comer com "cisma" (aborrecido), pois pode causar amolecimento do corpo e febre (SANTOS, 2008, p. 33).

Ainda hoje a mulher durante a menstruação segue regras que foram passadas de geração a geração. Há diversas crenças sobre esse delicado período feminino, nas quais não se sabe quando nem onde começaram. Vejamos algumas relacionadas à alimentação: a) Não se deve comer ovo, que causa mau cheiro; b) Evitar comer abacate, que é gorduroso e pode dar pus; c) Evitar tomar suco de cupuaçu, pode matar, aumentar a cólica ou causar hemorragia; d) Evitar qualquer fruta cítrica, aumenta o fluxo de sangue e pode causar hemorragia; e) Evitar tomar açaí, faz mal! Vai mudar a cor do sangue e causar inflamações. Estes são alguns exemplos de saberes populares entre as mulheres, mesmo as mulheres que tenham alcançado um grau de estudo formal mais avançado, muitas delas continuam a "obedecer" essas regras.

Ainda no caso das mulheres na fase do ciclo menstrual, no romance Menina que vem de Itaiara (CELINA, 1997) podemos verificar a dificuldade que certas mães tinham, na época, de falar claramente sobre esse assunto com as suas filhas, a citação a seguir denota essa realidade.

- Mamãe, que dores são estas, tão fortes, da Rita?

- É dor de madre, dor nos intelitos (mamãe assim denominava tudo quanto ficasse dentro da barriga, estômago etc.), moça que não se cuida, em certos dias, que anda na terra quente, come tamarindo, fruta ácida, carrega peso, toma banho de igarapé gelado sem poder, dá nisso. Vai botando tuas barbas de molho, estás vendo!" (CELINA, 1997, p. 196).

A citação acima mostra como a mãe de Rita usa algumas figuras de linguagem para ensinar a filha sobre o ciclo menstrual e suas consequências, expressando a dificuldade que as mães tinham de tratar claramente de assuntos dessa natureza com a própria filha.

Outro exemplo são os purgantes, eles nos fazem lembrar o terror da infância de nossos pais, como o caso da famosa "mamona", bastante presente em Menina que vem de Itaiara. Veremos alguns casos: "Sei de um pé de cajarana no quintal, um dia levei umas lambadas porque, às escondidas, me fartei de cajaranas, depois de um bruto purgante de mamona" (CELINA, 1997, p. 11).

Ainda em Menina que vem de Itaiara (CELINA, 1997) temos o purgante sendo receitado por um médico, como na transcrição a seguir.

Dr. Oscar foi das personagens dessa época uma que se plantou nas minhas lembranças para nunca mais. Não posso sentir o cheiro de chá de erva-cidreira que não o veja diante de mim, ele e seus purgantes pra vermes. Cada mês, aquele dia de 
juízo, mamãe me agarrando à força, o copo de mamona ${ }^{8}$ dissolvida em chá de cidreira na mão: “Engula, engula, senão apanha!”. Tive pena dele, abri a boca, ele virou a mamona com quenopódio, dissolvida no chá de cidreira. (CELINA, 1997, p. $15)$.

Provavelmente um dos primeiros métodos de cura que veio das plantas, o animal, instintivamente, quando adoece recorre às ervas curativas, o homem notou este gesto instintivo dos animais e, orientado por observações próprias, verificou-se que nas ervas há poder curativo. Desta forma, iniciaram-se as pesquisas em torno da natureza, especificamente com as ervas. "Tão perfeita é a natureza que provê tudo que necessitamos, pelas plantas todas doenças são curáveis, porém muitas curas ainda não foram descobertas”. (BALBACH, 1968, p. 45).

Para Balbach (1968), o mal muitas vezes se manifesta aos mais vulneráveis, por isso ficam propícios às enfermidades. Antes que uma doença possa ser classificada como diabetes, tuberculose, etc., por exemplo, há processos anormais que entorpecem o metabolismo nutritivo, mesmo outras enfermidades não podem surgir sem encontrarem um caminho preparado, se a pessoa estiver com suas funções orgânicas normais, primeiro a pessoa se predispõe para o mal, em seguida surgem, então, as desordens em todo mecanismo funcional, acumulam-se no organismo humores mórbidos, repletos de toxinas. Os micróbios encontram então um terreno propício para a sua atuação, se alastram, apesar da resistência que encontram da parte das defesas naturais do organismo enfraquecido.

Há que se falar também nas ervas com poder de danificar os órgãos, algumas com poder de até mesmo de levar a óbito, ervas com alto poder degenerativo. Ervas venenosas.

No romance, a protagonista Irene, diante do sofrimento da prima Diquinha, pensa que se conhecesse alguma erva, poria fim ao sofrimento da prima. Porém o sentido de acabar o sofrimento seria através da morte, não pela cura, mas o que importa entender no presente contexto, é a importância que as ervas têm no cotidiano das pessoas. Conforme retrata o texto a seguir.

Falei que tia Helga tinha uma filha aleijada. Não saía da cama e comia num prato de madeira ... vivia num quarto à parte, escondida. Não falava, não andava, tudo era pela mão dos outros ... Foi crescendo, foram percebendo que ficara inutilizada. Quando queria comer, chamar alguém, batia os pés ... Quando tive a certeza de que prima Diquinha jamais ficaria boa, nunca iria tomar um banho no rio, brincar, falar, correr como a gente ... Um dia, tive um pensamento horrível: soubesse eu de um mato, umas ervas, um chá, umas gotas ou pílulas, lhe faria beber. Soubesse dar injeção, possuísse uma dessas ampolas de matar, aplicaria, às escondidas, na minha pobre prima, assim que ela dormisse. Para que nunca mais acordasse (CELINA, 1997, p. 94).

Por isso, é um perigo certas porções de ervas ou acessos a ervas desconhecidas, ou até mesmo ingeri-las acidentalmente, como o uso prolongado e persistente.

Certa vez, a mãe de Irene percebeu a alteração da pressão de uma criança, Stela, sua afilhada, que estava em visita à sua casa, e novamente recorreu aos conhecimentos tradicionais na busca pela recuperação da saúde da criança, conforme relato a seguir:

\footnotetext{
${ }^{8}$ MAMONA- Ricinus communis - família: Euforbiáceas. Outros nomes: Ricino, carrapateiro, palma Cristo. Descrição: A mamona, quando nova, é uma planta herbácea que se lignifica com a idade, assumindo o aspecto de uma árvore pequena e muito esgalhada. USO MEDICINAL: das sementes, limpas das cascas, se obtém um óleo de efeito purgativo. O mesmo azeite também se presta para combater os vermes intestinais. As sementes são Tóxicas. "vinte delas, ingeridas por um adulto, geralmente lhe conduzem a morte. Seis a sete já liquidam uma criança. (BALBACH, 1968, p. 280).
} 


\begin{abstract}
"Astésia, esta criança tem febre". Astésia palpou-a: "Tem não, madrinha, é que estava dormindo". "Sim, mas não no abafado, com tudo aberto..." Conversa continuou, a Rita daí a pouco trouxe café com macaxeira, merendamos. Logo Deusarina, ama de Stela, apareceu com o prato com banana e aveia. Porém, ela recusou-se a comer. Mamãe tornou a palpá-la: "Astésia, Stela está doente, olha só a quentura, aumentou". Trataram de vesti-la, agasalha-la, fazer-lhe um chá de sabugueiro que teve que engolir bem quente ... Quando papai entrou, pelas dez horas, Stela tinha tombado num agitado sono, cheio de tremores, entrecortado de breves, inarticulados gritos. Mamãe com dificuldade deu-lhe água açucarada, e ela pegou noutro soninho, ligeiramente mais calmo. (CELINA, 1997, p. 101).
\end{abstract}

Em algumas ocasiões, as ervas deixam de trazer o êxito esperado no tratamento. Por vezes o paciente pode se sentir melhor e acabar abandonando o tratamento antes de alcançar uma cura total, pois o segredo da cura está no uso ordeiro e perseverante das plantas medicinais até que todo o mal seja extinto. Outras situações, é quando acontece um efeito contrário do que o paciente espera. Nesse caso, sobrevém uma aparente piora, e o mal parece agravar-se. Muitos, quando isso ocorre, ficam desesperados e abandonam o tratamento. Mas é justamente esta crise um sinal de que o organismo começou a reagir, expulsando as substâncias morbosas. O remédio está fazendo efeito. (BALBACH, 1968, p. 55).

O sabugueiro 9 (Sambucus nigra) é uma das plantas medicinais mais utilizadas no mundo. É bastante utilizado para tratar os sintomas da gripe e do resfriado. Na narrativa, aconteceu justamente esta reação com o chá, como se tivesse agravado a febre com o sabugueiro. Essa reação é natural quando o organismo começa a reagir. O simples ato de dar água açucarada é como se fosse a solução, de cortar efeito ou superstição da mãe em depositar sua fé.

No romance ainda temos a receita de Vijoca "não tardou a aparecer quem pedisse a fórmula da garrafada. Mamãe, prestativa, fez ela própria uma porção, que pela vizinhança distribuiu" (CELINA, 1997, p. 106). Esse relato refere-se à garrafada, termo usado para uma combinação de ingredientes, dos mais diversos possíveis, tais como: ervas, frutas, cascas, alguns chegam a conter até pedaços de animais etc., produzidos com algumas exigências de tempo, de preparo, de sequência etc., após a preparação o composto é guardado em uma garrafa (daí o nome garrafada), geralmente de vidro e, normalmente, combate para uma grande quantidade de doenças. Há diversos tipos de garrafadas, com os mais variados objetivos. A seguir, segue o relato de Irene sobre a garrafada:

\footnotetext{
${ }^{9}$ SABUGUEIRO - Sambucus nigra - Família: Caprifoliáceas. Outros nomes: Sabugueiro da Europa. Descrição: Pequena árvore, de 3 a 4 metros de elevação. Tronco de casca pardacento-acinzentada, verrugosa, folhas opostas, compostas imparipenadas, de 5 a 7 folíolos curtamente peciolados, oval-lanceolados, acuminados, serreados. Este é o sabugueiro da europa, o sabugueiro muito conhecido do Brasil é o Sambucus australis. O primeiro produz frutos comestíveis ao passo que este último nunca os produz. Na medicina caseira ambos têm a mesma aplicação. USO MEDICINAL: As flores são eméticas, catárticas. Porém, quando secas, perdem suas propriedades laxativas, secas empregam-se, em infusão, contra os resfriados, as anginas, as gripes, etc. A casca, a raiz e as folhas são indicadas na retenção da urina, na hidropisia, no reumatismo. Os reumáticos devem igualmente tomar banho com o cozimento das folhas. A infusão das folhas e cascas, em fomentações, é prescrita contra as inflamações superficiais da pele, furúnculos, erisipela, queimaduras etc. Neste último caso, também se aplicam diretamente as folhas machucadas. Tiram a dor em pouco tempo. Em banhos as folhas são boas para hemorroidas. Nas enfermidades eruptivas, como no sarampo, rubéola, escarlatina, varíola, etc. O chá das flores é muito indicado, porque provoca rapidamente a transpiração. A frutinha purifica o sangue e limpa os rins. Seca, tostada, moída e preparada como café, é boa para cortar a diarreia. Dose: Uso interno - flores, 8 gramas para 1 litro de água; folhas, cascas e raízes, 10 a 15 gramas para 1 litro de água; 4 a 5 xícaras por dia. Uso externo - flores, 30 gramas para 1 litro de água; folhas, cascas e raízes, 50 gramas para 1 litro de água. (BALBACH, 1968, p. 315).
} 


\begin{abstract}
"Também a Vijoca me curou de uma tosse dos diabos. Nem precisou vir ter conosco. Concentrou-se mesmo onde estava dando consultas, na Boca-do-Caminho, e receitou:

- Apeí, fedegoso, mussambê, flor de mamão macho, raiz e fruta de urucu, cebolinha, gengibre, mandacaru (ela chamava jaramacaru), jambu, laranja-da-terra, raiz de manjerioba (também chamada de pamarioba), açúcar branco, mel de abelha. Tudo cozido em lambedor.

Receitas de Vijoca era, pá-casca. Diz mamãe que foi eu tomar a primeira colherada, e se notou melhora. Com tão pronto efeito, não tardou a aparecer quem pedisse a fórmula da garrafada. Mamãe, prestativa, fez ela própria uma porção, que pela vizinhança distribuiu. A asma de Tereza, filha de seu Guimarães, uma asma velha, de dez anos, curou-se. A tosse de cachorro de João Mandu, idem. João Mandu habitava bem um quarteirão abaixo de nossa casa, na rua do Capim. Pois sua tosse muitas noites impedia o sono de meus pais, tão longe e tão fundo ecoava. E não é que o homem ficou bonzinho dessa bronquite de anos, apenas com uma garrafada? Só para mamãe, lambedor de Vijoca nunca fez efeito. Podia-o tomar às carradas, bem nenhum lhe advinha para uma rouquidão, um catarro, uma piema, antes piorava. Mas mamãe sempre afirmou que seu organismo era diferente do de todo mundo. Magnésia que para qualquer cristão é laxante, para ela, o mesmo que água, vidros inteiros que ingerisse. Produzia até efeito contrário...” (CELINA, 1997, p. 106) (Grifo nosso).
\end{abstract}

No fragmento especificado, encontramos a citação de um composto de ervas, de plantas medicinais, de cascas e de outros ingredientes. Todos próprios da região bragantina. Quando em quantidade certa, um preparo especial, com minuciosa sequência e ações coordenadas, se transforma na chamada garrafada, que era muito usada naquela época e até hoje ainda o é, porém em menor frequência. Era usada para as mais variadas doenças e males, como no próprio texto cita alguns exemplos: asma, tosse e bronquite. Ainda hoje encontramos pessoas que utilizam este composto. Como exemplo, temos as profissionais do sexo que, na maioria das vezes, exercem a prostituição como meio de sustento familiar. Após uma relação sexual com as pessoas que atendem profissionalmente, para que não adquiram doenças dos seus "clientes", ingerem doses da garrafada para a limpeza e proteção do corpo. Algumas profissionais do sexo acreditam que a garrafada serve, inclusive, como material anticonceptivo, para evitar uma gravidez indesejada. Também é fácil encontrarmos esses compostos nas farmácias de manipulação, locais que funcionam como laboratórios de produção dessas combinações de ervas e plantas medicinais e as comercializam em garrafas de um litro, meio litro, ou frascos com doses pequenas. Alguns desses locais ainda oferecem o benzimento e rezas, porém com o nome de consulta ou exame.

\title{
3 CONSIDERAÇÕES FINAIS
}

A pesquisa empreendida no romance Menina que vem de Itaiara (CELINA, 1997), trouxe-nos um olhar mais cuidadoso com a alimentação, com a saúde, e a relação entre elas, como a primeira influencia a segunda numa relação complexa de troca, parceria ou adversidade. Trouxe também a presença de certos remédios caseiros, como purgantes, chás e a garrafadas, estas usadas quando as mulheres estão com problemas de útero, também há outros tipos de garrafada muito usada para curar problemas nos pulmões, gripes, tosses etc. Explora também o lado feminino, quando as mulheres no período menstrual não podem comer certos alimentos.

Também tem grande destaque os diversos tipos de ervas, que são benéficas para muitos problemas de saúde, sem deixar de mencionar os curandeiros e benzedeiros presentes no romance, e que ganha grande destaque em Bragança, a qual ainda tem benzedeiras com tais habilidades para curar, de maneira mais prática certas doenças. 
Consideramos que a presente análise foi importante para alcançarmos um maior conhecimento sobre certos alimentos nutritivos para a saúde do corpo, assim como plantas medicinais. Esperamos que esta pesquisa contribua para futuros estudos, por meio desta obra que nos possibilitará entender um pouco mais da literatura paraense pela composição de Lindanor Celina. $\mathrm{O}$ trabalho pode trazer mais discussões sobre elementos não explorados do romance, assim como poderá servir como inspiração para futuras pesquisas, quiçá seja de grande importância para a comunidade acadêmica amazônica.

\section{REFERÊNCIAS}

ARAÚJO, Alceu Maynard. Medicina Rústica. Brasiliana. Vol. 300 - 3 ed. São Paulo: Nacional, 1959.

BALBACH, A. As Plantas Curam. 24ª ed. Editora: M.V.P. São Paulo: 1968.

Bíblia Sagrada. Ezequiel 47,12. A fonte maravilhosa que jorra do templo. Tradução Monges Beneditinos de Maredsous (Bélgica). ed:195ª São Paulo: Editora Ave-Maria, 2011.

Bíblia Sagrada. Genêsis, 1,11-12. A criação. Tradução Monges Beneditinos de Maredsous (Bélgica).195ª ed. São Paulo: Editora Ave-Maria 2011.

CELINA, Lindanor. Menina Que Vem de Itaiara. Rio de Janeiro: Conquista, 1997.

GEERTZ, Clifford. A interpretação das culturas. Rio de Janeiro: LTC, 2012.

LIMA, Walter Chile Rodrigues. Saber Tradicional: Suporte para o exercício da Territorialidade de uma Comunidade no Estuário Amazônico. In: Revista Ensaio Geral. Belém, v.1, n. 1, Jan-jun. 2009.

PACHECO, Sandra Simone Moraes. O hábito alimentar enquanto comportamento cultural produzido. In: FREITAS, Maria do C. Soares de; FONTES, Gardênia A. V.; OLIVEIRA, Nilce. Escritas e narrativas sobre alimentação e cultura. Salvador: EDUFBA, 2008. 422 p.

ROMÃO, Tito Lívio Cruz. Sincretismo Religioso como Estratégia de Sobrevivência Transnacional e Translacional: divindades africanas e santos católicos em tradução. In:

Trabalhos em Linguística Aplicada. On-line version ISSN 2175-764X. Trab. linguist. apl. vol. 57, n.1. Campinas: Jan./Abr. 2018, disponível:

https://doi.org/10.1590/010318138651758358681. Universidade Federal do Ceará, Fortaleza (CE), Brasil. cruzromao@terra.com.br. Acesso em 13/04/2020.

SANTOS, Fábio Rodrigo dos. Práticas alimentares em Ilha de Maré, Salvador, Bahia. In: FREITAS, Maria do C. Soares de; FONTES, Gardênia A. V.; OLIVEIRA, Nilce. Escritas e narrativas sobre alimentação e cultura. Salvador: EDUFBA, 2008. 422 p. 